\title{
Editorial \\ Blended Learning and Teaching in Higher Education: An International Perspective
}

\author{
Francesca Amenduni ${ }^{1, *}$ and Maria Beatrice Ligorio ${ }^{2, *(D)}$
}

Citation: Amenduni, F.; Ligorio, M.B. Blended Learning and Teaching in

Higher Education: An International

Perspective. Educ. Sci. 2022, 12, 129.

https://doi.org/10.3390/

educsci12020129

Received: 7 February 2022

Accepted: 9 February 2022

Published: 16 February 2022

Publisher's Note: MDPI stays neutral with regard to jurisdictional claims in published maps and institutional affiliations.

Copyright: (C) 2022 by the authors. Licensee MDPI, Basel, Switzerland. This article is an open access article distributed under the terms and conditions of the Creative Commons Attribution (CC BY) license (https:// creativecommons.org/licenses/by/ $4.0 /)$.

1 Department of Educational Technologies in Vocational Education and Training, Swiss Federal University for Vocational Education and Training-SFUVET, 6900 Lugano, Switzerland

2 Department of Education, Psychology and Communication, Università degli Studi di Bari, 70121 Bari, Italy

* Correspondence: Francesca.amenduni@suffp.swiss (F.A.); mariabeatrice.ligorio@uniba.it (M.B.L.)

Blended learning is not a new topic for educational research in Higher Education (HE). However, before the first wave of the COVID-19 pandemic, blended learning was studied by a "niche" of researchers and educators interested in technology integration in teaching and learning. It was not difficult to meet HE professionals who had never or had only poorly reflected on the topic of how to integrate digital technology in teaching and learning before March 2020. Many authors acknowledge the effectiveness of blended learning over face-to-face traditional courses [1,2]. Nortvig and her colleagues [3] proposed a more comprehensive comparison, which included e-learning with only online formats, a blended approach that mixed online and face-to-face teaching with in-person teaching. According to their review, it is clear that is not easy to compile a ranking and point out the best method, as many other factors influence the effectiveness of a teaching method, such as educator presence in online settings, the interactions between students, teachers and content, and deliberate connections between online and offline activities and between campus-related and practice-related activities.

The pandemic forced even the most skeptical HE actors (teachers, students, and deans) to deal with educational technologies. This shift to what we currently call Emergency Remote Teaching [4] brought mixed results, which can be explained by organizational aspects (e.g., infrastructure), teacher and student digital competences, and instruction modes. Despite the emergency, in a few cases, research shows better learning outcomes during the forced distance teaching period compared to traditional face-to-face classes before the pandemic $[5,6]$.

Even in the most negative contexts, it was possible to experience positive aspects, such as opportunities for teachers' professional development. We recognize that these opportunities have not yet been fully exploited and we consider that understanding how to capitalize on the lessons received during the lockdown for the future is the next challenge. Indeed, the new educational scenarios are-at different speeds according to the pandemic scenario-going back to in-person teaching; however, many do not want to give up technology and the possibility of using education at a distance. In other words, the blended solutions are going to be even more popular.

Blended learning seems to be a favorable solution and is a field which has already attracted some attention; now, we need to re-focus on this, capitalize on what we have learned from the current situation, and combine them with what we already know from previous research.

The most basic definition of blended learning encompasses the possible combination of computer-mediated and face-to-face teaching. It is not a simple juxtaposition of physical presence and technological mediation, but a well-studied alternation of the two, aiming to make the most of the various components and design effective work contexts for both students and teachers. 
Although this definition of blended learning is generally accepted, a huge variety of practices have been developed under this terminology. In light of the new technological awareness that educational settings have reached, there is a need to provide more detailed instructions and suggestions regarding how to design, implement, monitor, and assess blended learning.

The six papers presented in this Special Issue begin to answer to a few critical questions related to learning models, cognitive and social processes that could be intertwined in a blended learning program in $\mathrm{HE}$ and communication modes.

By looking at the six papers, blended learning has been interconnected with a theoretical model of constructive and interactive learning, specifically with collaborative knowledge construction [7-10], collaboration with external professional communities [11] and collaboration aimed at conceptual problem-solving [12].

Soliman et al. [10] described how synchronous and asynchronous Knowledge Building can be combined in new ways to provide students with more design time and a deeper engagement with the content and their peers. In Bent et al. [7], pre-service teachers developed their collective expertise through peer-feedback on video recordings of their professional practice. Through semantic network analysis, authors retrieved the progressive knowledge development of the pre-service teachers, which, at the end of the semester, adopted a new specialized vocabulary and were more able to interconnect conceptual topics. Ritella and Loperfido [8] described that a student-centered approach, such as Knowledge Creation, requires HE students to develop self-organization strategies in blended learning contexts. According to their findings, group self-organization changed across different phases of the collaborative task and involved the development of specific practices of self-organization. Sansone et al. [9] presented how a blended HE course could be enhanced through a Design-based research approach by improving students' perception of the acquisition of skills and knowledge through the different course editions. In the case of Amenduni et al. [11], collaboration occurred between an HE educational community and external professional communities. The participation of company tutors in an instant messaging environment moved HE students toward a more collaborative and reflective dynamic. Finally, Stahl [12] described the collaborative use of existing dynamic-geometry technology for Euclidean geometry (GeoGebra). The technology allows teachers and students to interact with the same material in multiple modes, so blended approaches can be flexibly adapted to students with diverse preferred learning approaches or needs, and structured into parallel or successive phases of blended learning. The technology can be used by online students, co-located small groups and school classrooms, with teachers and students having shared access to materials and student work across interaction modes.

The six papers described different Communication and collaboration modes-i.e., asynchronous or synchronous-which are involved and interconnected with the various existing platforms. Soliman et al. [10] described the combined use of Zoom for synchronous communication with the Knowledge Forum for asynchronous knowledge construction activities. Bent et al. [7] used the Iris Connect environment for students to upload their recordings of their teaching activities at VET schools. Communication between students occurred within the Iris Connect environment in the form of peer feedback among pre-service teachers. Amenduni et al. [11] described the use of Whatsapp as an instant messaging environment to support communication within an academic community (composed of students and academic and tutors) and between academic and professional community (composed of students, academic and company tutors). Sansone et al. [9] described the combination of different communication and collaboration environments: Moodle (for discussion), Padlet (for brainstorming) and Google Suite for collaborative activities (e.g., collaborative maps and writing). Stahl presented a recent feature of the GeoGebra environment, the "class function", in which a teacher can invite several students (a pod) to work on their own versions of the same construction, and the teacher can view each student's construction work and discussion in a Class dashboard. 
Overall, this Special Issue provides a deeper understanding of what Blended Learning will be in the near feature, encompassing not the simple combination of online and physical presence, but a combination of delivery tools and media used to provide information and support interaction, a combination of different methods of instruction and teaching/learning, and a combination of learning contexts.

Conflicts of Interest: The authors declare no conflict of interest.

\section{References}

1. Bernard, R.M.; Borokhovski, E.; Schmid, R.F.; Tamim, R.M.; Abrami, P.C. A meta-analysis of blended learning and technology use in higher education: From the general to the applied. J. Comput. High. Educ. 2014, 26, 87-122. [CrossRef]

2. Vo, H.M.; Zhu, C.; Diep, A.N. The effect of blended learning on student performance at course-level in higher education: A meta-analysis. Stud. Educ. Eval. 2017, 53, 17-28. [CrossRef]

3. Nortvig, A.M.; Petersen, A.K.; Balle, S.H. A Literature Review of the Factors Influencing E Learning and Blended Learning in Relation to Learning Outcome, Student Satisfaction and Engagement. Electron. J. E-Learn. 2018, 16, 46-55.

4. Hodges, C.B.; Moore, S.; Lockee, B.B.; Trust, T.; Bond, M.A. The Difference between Emergency Remote Teaching and Online Learning. 2020. Available online: https:/ / er.educause.edu/articles/2020/3/the-difference-between-emergency-remote-teachingand-online-learning (accessed on 15 February 2022).

5. Gonzalez, T.; De La Rubia, M.A.; Hincz, K.P.; Comas-Lopez, M.; Subirats, L.; Fort, S.; Sacha, G.M. Influence of COVID-19 confinement on students' performance in higher education. PLoS ONE 2020, 15, e0239490. [CrossRef] [PubMed]

6. Iglesias-Pradas, S.; Hernández-García, Á.; Chaparro-Peláez, J.; Prieto, J.L. Emergency remote teaching and students' academic performance in higher education during the COVID-19 pandemic: A case study. Comput. Hum. Behav. 2021, 119, 106713. [CrossRef] [PubMed]

7. Bent, M.; Velazquez-Godinez, E.; De Jong, F. Becoming an Expert Teacher: Assessing Expertise Growth in Peer Feedback Video Recordings by Lexical Analysis. Educ. Sci. 2021, 11, 665. [CrossRef]

8. Ritella, G.; Loperfido, F.F. Students' Self-Organization of the Learning Environment during a Blended Knowledge Creation Course. Educ. Sci. 2021, 11, 580. [CrossRef]

9. Sansone, N.; Cesareni, D.; Bortolotti, I.; McLay, K.F. The Designing and Re-Designing of a Blended University Course Based on the Trialogical Learning Approach. Educ. Sci. 2021, 11, 591. [CrossRef]

10. Soliman, D.; Costa, S.; Scardamalia, M. Knowledge Building in Online Mode: Insights and Reflections. Educ. Sci. 2021, 11, 425. [CrossRef]

11. Amenduni, F.; Annese, S.; Candido, V.; McLay, K.; Ligorio, M.B. Blending Academic and Professional Learning in a University Course for Future E-learning Specialists: The Perspective of Company Tutors. Educ. Sci. 2021, 11, 415. [CrossRef]

12. Stahl, G. Redesigning Mathematical Curriculum for Blended Learning. Educ. Sci. 2021, 11, 165. [CrossRef] 